\title{
Antibodies on demand: a fast method for the production of human scFvs with minimal amounts of antigen
}

\author{
Ingrid Babel ${ }^{\dagger}$, Rodrigo Barderas ${ }^{\dagger}$, Alberto Peláez-García and J Ignacio Casal $^{*}$
}

\begin{abstract}
Background: Antibodies constitute a powerful tool to study protein function, protein localization and proteinprotein interactions, as well as for diagnostic and therapeutic purposes. High-throughput antibody development requires faster methodologies with lower antigen consumption.

Results: Here, we describe a novel methodology to select human monoclonal recombinant antibodies by combining in vitro protein expression, phage display antibody libraries and antibody microarrays. The application of this combination of methodologies permitted us to generate human single-chain variable fragments (scFvs) against two proteins: green fluorescent protein (GFP) and thioredoxin (Trx) in a short time, using as low as $5 \mu \mathrm{g}$ of purified protein. These scFvs showed specific reactivity against their respective targets and worked well by ELISA and western blot. The scFvs were able to recognise as low as $31 \mathrm{ng}$ of protein of their respective targets by western blot.

Conclusion: This work describes a novel and miniaturized methodology to obtain human monoclonal recombinant antibodies against any target in a shorter time than other methodologies using only $5 \mu \mathrm{g}$ of protein. The protocol could be easily adapted to a high-throughput procedure for antibody production.
\end{abstract}

Keywords: scFv antibodies, in vitro protein expression, phage display, antibody microarrays

\section{Background}

A crucial challenge of the proteome era is to use the genome information for a better understanding of protein expression, protein cellular distribution and functionality discovery not only in normal but also in pathological processes [1,2]. Antibody development against every human protein is a prerequisite to improve this knowledge. Several high-throughput alternatives have been developed to generate antibodies to the entire proteome [3-5]. The Human Protein Atlas initiative (http://www.proteinatlas.org/) [3,4], the Sanger Institute Antibody Atlas Database, the NCI Clinical Proteomics [5], the HUPO human antibody initiative (http://www. hupo.org/research/hai/) [6], and several EU-funded consortia (ProteomeBinders, AffinityProteome, Affinomics

\footnotetext{
* Correspondence: icasal@cib.csic.es

† Contributed equally

Functional Proteomics Laboratory. Centro de Investigaciones Biológicas (CIBCSIC). Ramiro de Maeztu 9, Madrid 28040, Spain
}

[7-9]; http://www.proteomebinders.org) are all good examples of these alternatives.

The production of $\mathrm{mAbs}$ and/or rabbit antibodies requires large amounts of antigens, it is time-consuming due to the immunization step of the animals and, in the case of mAbs, the screening and clone selection can take from 6 months to 1 year [10].The development of recombinant antibodies in single-chain $\mathrm{Fv}(\mathrm{scFv})$ formats is a good alternative to obtain high-affinity antibodies against any target without time-consuming immunization [11-14]. The affinity of scFvs for their targets might be comparable to that of mAbs or pAbs and in some cases even higher [15]. As a general rule, scFvs possess several advantages in comparison to IgG or Fabs such as higher tissue penetrance and more rapid clarification $[16,17]$. Moreover, antibody phage display, M13-based human libraries, is becoming particularly useful for the production and development of antibodies for immunotherapy in different diseases [18-21]. In vitro phage

C Biomed Central

(c) 2011 Babel et al; licensee BioMed Central Ltd. This is an Open Access article distributed under the terms of the Creative Commons Attribution License (http://creativecommons.org/licenses/by/2.0), which permits unrestricted use, distribution, and reproduction in any medium, provided the original work is properly cited. 
display pipelines have been setup to generate antibodies to the complete human proteome, but the selections are still carried out manually $[8,9,22]$. Screening of phage display antibody libraries is constrained by the necessity of having considerable amounts of antigen, at least 0.1$0.5 \mathrm{mg}$ of protein for the whole procedure (selection, screening and validation).

The necessity of having significant amounts of the purified target protein, not only for production and selection but also for the screening of antibodies, is one of the main problems to develop antibodies, and constitutes a major bottleneck associated to all three alternatives above described [10]. Despite progress in automation, protein expression is a limiting step to get toxic, difficult-to-express or membrane proteins. Rapid, efficient, and cost-effective protein expression and purification strategies are required for the production of antibodies against any target, trying to minimize at the same time, the amount of required protein.

Cell-free expression is a powerful and flexible technology. New advances in this technology have faced the higher demand for high-throughput protein synthesis. These advances include the use of cell-extracts from different backgrounds (prokaryotic or eukaryotic), modulation of the reducing environment for the correct production of disulfide bonds, incorporation of detergents, lipid bilayers or other non-lipoprotein particles for the expression of membrane proteins and, finally, the automation of the procedure [23-26]. Furthermore, cell-free systems offer several advantages over traditional cell-based expression methods, which include lower sensitivity to product toxicity and suitability for highthroughput strategies, because of reduced reaction volumes and processing time. Recent improvements in translation efficiency have resulted in yields comparable to cell-based expression systems for difficult-to-express proteins [27-30].

Bacterial, wheat germ and reticulocyte lysates have been used as in vitro expression systems in a wide variety of strategies [31]. Rapid Translation System (RTS) [32], a bacterial-based commercially available cell-free protein expression system, has been used for the high-throughput expression of inner and outer membrane proteins from Anaplasma marginale [33]. In 2000, the Riken Structural Genomics Initiative (Japan) reported the bacterial based cell-free protein expression production of about $25 \%$ of randomly chosen mouse cDNA clones with yields higher than $0.1 \mathrm{mg} / \mathrm{ml}$ [34]. Since then, several developments have significantly improved the yield of in vitro expressed proteins in the range of milligrams of protein per $\mathrm{mL}$ of reaction mix $[27,28,35,36]$. Another interesting initiative is the "human protein factory", for the expression of human proteins using the wheat-germ in vitro protein expression system and Gateway technology [24]. The authors reported a 97\% success rate of protein expression over 13364 human proteins. Among them, they detected soluble proteins in 12682 out of 13364 clones [24]. There have been other successful high-throughput initiatives based on in vitro protein expression, with yields up to $6 \mathrm{mg} / \mathrm{mL}$, which have been applied for protein arrays, nuclear magnetic resonance and crystallization studies [37-39].

Regarding the use of low amounts of protein, the microarray format is particularly useful for low consumption and automation. Antibody arrays were initially designed to capture and detect simultaneously multiple analytes with high affinity and selectivity in human biological samples (plasma, serum, tissue ...) in order to study variations between biological statuses [5]. We have explored the use of this proteomic technique for testing scFv antibody libraries against different antigens at the same time in order to identify specific scFvs, increasing the throughput of the screening step with minimal requirements of protein. In this report, we propose a novel methodology to develop scFv antibodies using human phage display antibody libraries in a short time (no more than four weeks) with only $5 \mu \mathrm{g}$ of protein. Furthermore, this method could be automated in a high-throughput format to obtain "antibodies on demand" against any target, taking advantage of cell-free protein expression, antibody phage display and $\mathrm{scFv}$ antibody microarrays.

\section{Results}

Production of human scFvs against cell-free expressed antigens

The cDNAs-encoding GFP and Trx were cloned into pIVEX and pET32b plasmids, respectively, and used for the in vitro transcription/translation reactions. The cellfree expression yielded between $5-10 \mu \mathrm{g}$ of purified protein per $50 \mu \mathrm{L}$ RTS reaction. The purity and homogeneity of the expressed proteins were confirmed by SDSPAGE and western blot using $10 \mu$ l of RTS reaction (Figure 1A, B).

Proteins were immobilized on the TALONTM magnetic beads and used to get antibodies by phage display. After extensive washing with PBS, TALON Dynabeads ${ }^{\circledR}$ were divided in five tubes containing $10 \mu \mathrm{L}$ of beads, one for each of the four rounds of selection with the libraries and the fifth one for Alexa Fluor 647-protein labelling. A remarkable phage enrichment for both proteins was observed by ELISA after 3 or 4 rounds of biopanning (Figure 1C).

\section{scFv antibody microarray preparation}

A total of 192 scFvs from each specific antigen selection were recovered from the $3^{\text {rd }}$ and $4^{\text {th }}$ round of selection, purified from the periplasmic fraction of HB2151 E. coli cells and directly printed in duplicate onto FAST nitrocellulose slides (Figure 2A)[40-42]. Although some scFv 


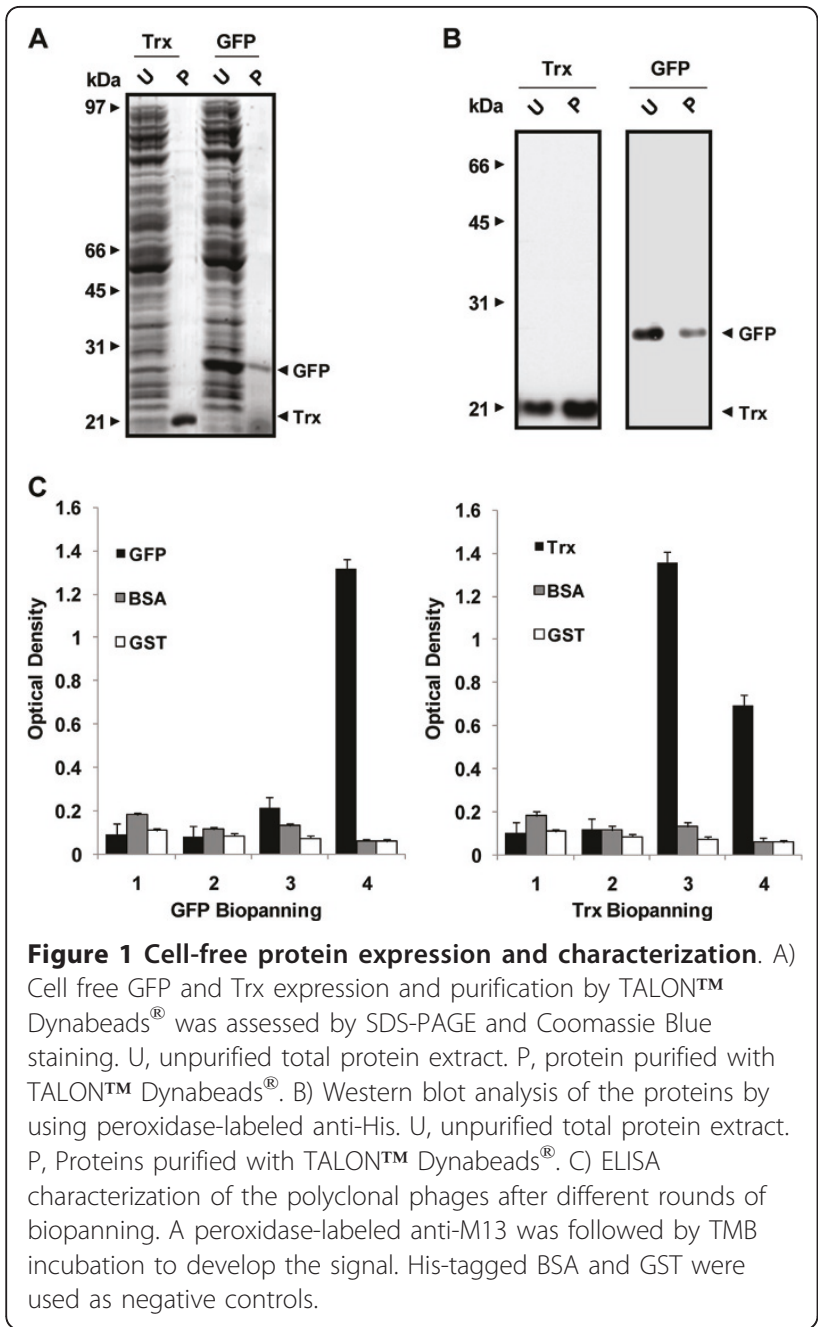

expression differences were observed among the different clones, a correct printing pattern was detected, indicating adequate printing conditions (Figure 2B). The amount of scFv printed in the array was determined by printing serial 1:10 dilutions of previously reported antigastrin $\mathrm{TA} 4 \mathrm{scFv}$ at $0.5 \mu \mathrm{g} / \mathrm{ml}$ to construct a regression line [40]. Then, we used the median of the fluorescence signal of the scFvs in the regression line to get the amount of scFvs printed in the array. Approximately 12 pg of antibodies were printed in each spot of the array. The quality of the scFv antibody microarray was confirmed by the absence of cross contamination between successive spots. All positive controls as well as buffer spots showed the correct reactivity. The intra-assay reproducibility was assessed by comparing the results between the two replicas printed within the same chip for each clone and gave an $R^{2}=0.9311$ (Figure 2C).

\section{Evaluation of specific scFvs in microarray format}

Evaluation of specific scFvs against GFP and Trx was performed by using scFv antibody microarrays. Cell-free

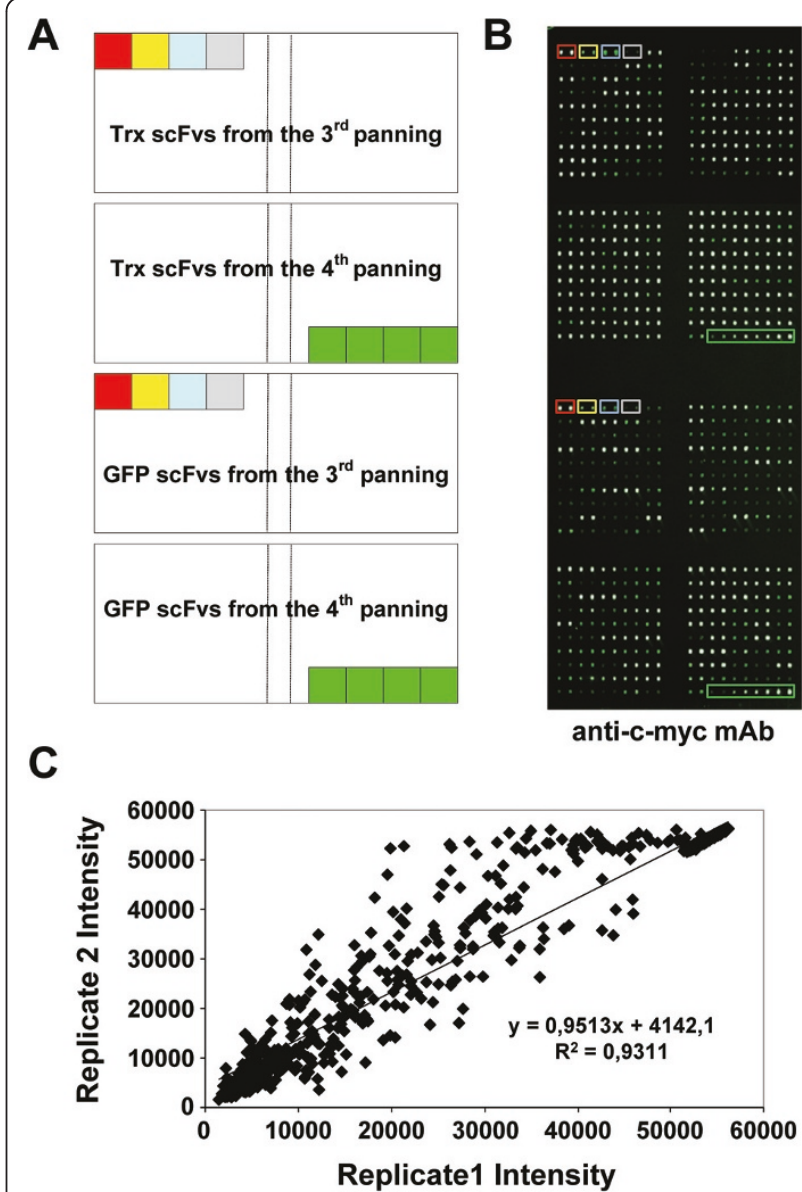

Figure 2 Printing conditions and scFv antibody microarrays reproducibility. A) Printing map of a microarray comprising 384 scFvs against GFP or Trx. Controls used in the assay were: red box, mAb anti-T7Tag, 1:10 diluted. Yellow box, mAb anti-T7Tag 1:100 diluted. Blue box, crude Trx (top) or GFP (bottom) RTS extract 1:10 diluted. Grey box, printing buffer. Green box, TA4 anti-gastrin17 scFv; from right to left 1:10, 1:100, 1:1000 and 1:1000 dilutions. B) A representative image of a microarray probed with an anti-c-myc antibody to assess the correct printing of the scFvs. For detecting cmyc antibody, slides were incubated with Alexa Fluor 555-labeled goat anti-mouse lgG antibodies. White spots indicate a saturation of the green signal intensity. C) scFvs were spotted in duplicate onto FAST nitrocellulose coated slides to verify the intra-assay reproducibility. Replicated spots showed a uniform intensity either visually or by GenePix analysis. The two intensity values for each clone were quantified and plotted to assess the intra-array reproducibility.

expressed and purified GFP and Trx proteins were directly labeled with 647 Alexa Fluor at $1 \mu \mathrm{g} / \mathrm{mL}$ to be probed in the antibody microarrays (Figure 3 ). In our microarrays, 384 recombinant scFvs were simultaneously tested. The scFvs obtained against each other antigen were also used as controls for the selection of highlyspecific scFvs that did not show cross-reactivity to other antigen (Figure 3A,C). 


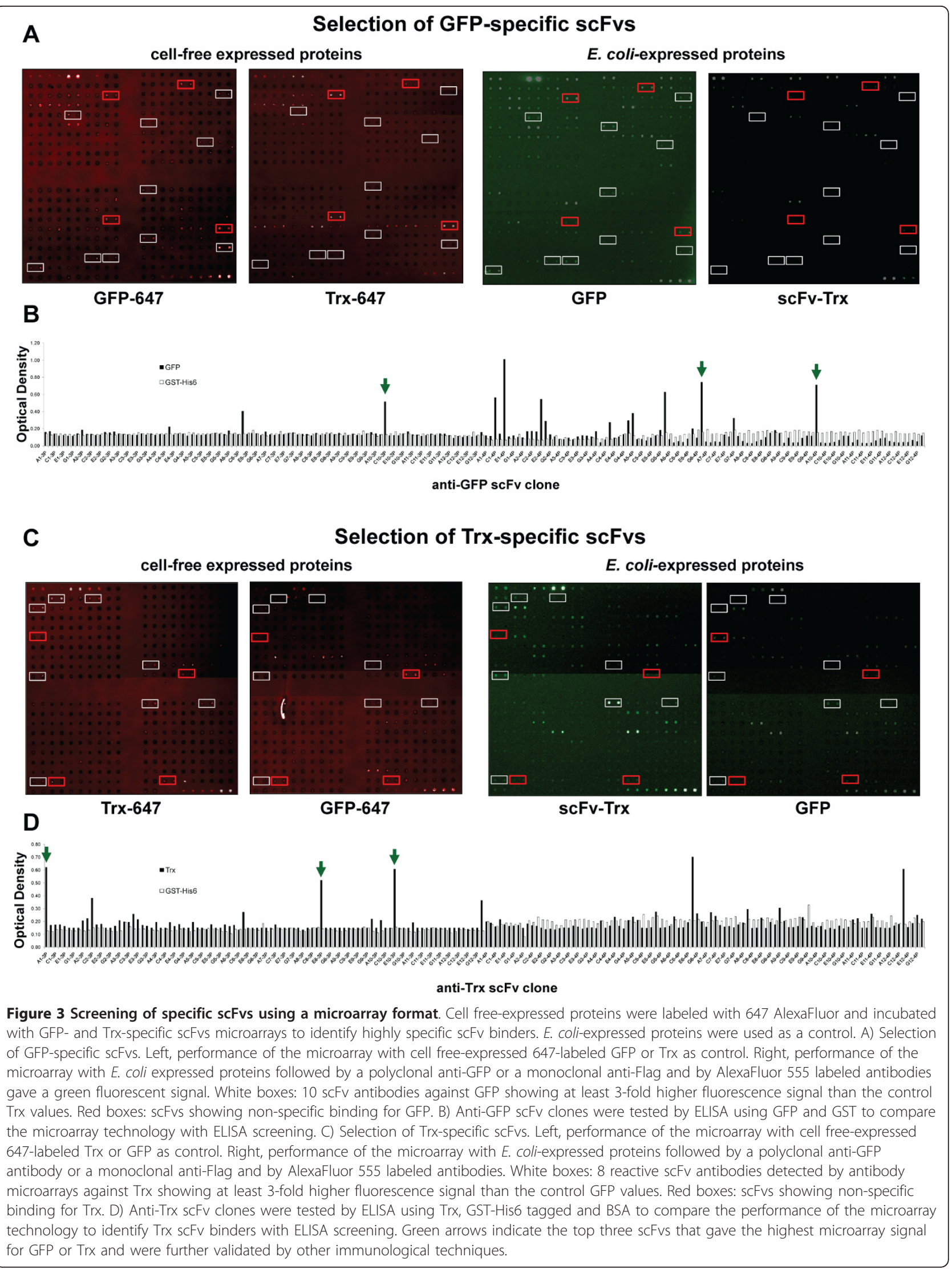


To test the reproducibility and selectivity of the system, we used also GFP and Trx proteins expressed in $E$. coli, followed by a fluorescent labelled antibody (Figure $3 \mathrm{~A}, \mathrm{C})$. Although signal intensity was usually stronger and background fluorescence was lower for the E. coliderived proteins, a similar reactivity pattern was observed for the cell-free Alexa647-labeled purified protein (red) or the E. coli-expressed GFP and Trx (green), indicating an adequate performance of the expression system and the microarray screening.

To check the effect of a potential $\mathrm{scFv}$ denaturation during printing and to demonstrate the utility of the screening by antibody microarrays, we tested all the $\mathrm{scFv}$ binders for each antigen by ELISA. A comparable number of $\mathrm{scFv}$ binders were found by ELISA and by antibody microarrays. By antibody microarrays, we found $10 \mathrm{GFP}$-specific scFvs with 3-fold higher signals than the negative controls (microarray incubated with Trx). By ELISA, we found 13 scFvs with at least 2-fold higher signals than the negative controls (Figure 3B), obtaining a $62 \%$ of coincidence (8 GFP-specific scFvs) between ELISA and antibody microarray. Regarding Trx scFv binders, we found by ELISA 8 scFvs with 2-fold higher signals than the negative controls (Figure 3D). By antibody microarrays (Figure $3 \mathrm{C}$ ) we also found 8 Trxspecific scFvs with 3 -fold higher signals than the negative controls (microarray incubated with GFP). Indeed, we were able to detect 6 Trx scFv binders by both techniques, with a $75 \%$ coincidence between both techniques. Collectively, these data support the use of antibody microarray screening to identify highly-specific $\mathrm{scFv}$ antibodies as an alternative to conventional ELISA.

\section{Characterization of the selected scFvs}

To confirm the value of the scFvs obtained by antibody microarray screening, we characterized the three scFvs showing strongest reactivity against each in vitroexpressed antigen. These scFvs were tested by ELISA to compare their reactivity against the in vitro-expressed proteins and the $E$. coli-expressed proteins. The results were similar for the three anti-GFP scFvs (GFP-H6, GFP-C10 and GFP-A10) (Figure 4A, B). The two scFvs that showed strong recognition by antibody microarrays were also the best for ELISA. However, although TrxA1 and Trx-E8 worked well in both assays (Figure 4A, B), Trx-E10 scFv showed a lower correlation between antibody microarrays and ELISA values.

The 6 scFvs selected (three per antigen) recognised their target proteins by western blot analysis, without cross-reactivity (Figure $4 \mathrm{C}$ ). Indeed, most of the scFvs were able to detect as low as $31.3 \mathrm{ng}$ of protein by western-blot, indicating the suitability of the scFvs for this technique. Indeed, Trx-A1 and Trx-E8 only showed 2-4 times lower sensitivity to Trx than M2 mAb to the Flag epitope (Figure 4C). Finally, the six scFvs were sequenced. All the scFvs-encoding DNA sequences were different (data not shown). The scFvs displayed significant variability not only in the CDRs but also in the framework as a consequence of the naïve origin of the Mehta libraries.

\section{Discussion}

Antibodies are used to study protein expression and localization within a tissue, cell or organelle, proteinprotein interactions or protein function $[1,4,14,43,44]$. Moreover, antibodies have multiple clinical uses for the diagnosis and treatment of diseases [5,20,21,45].

To study and characterize the human proteome, it is necessary to establish high-throughput methodologies for testing multiple antibodies against different proteins $[10,12,13,46]$. Here, we propose a new methodology to raise antibodies to any potential protein target: "antibodies on demand". This is a fast method to obtain recombinant human monoclonal antibodies against any antigen. Only $5 \mu \mathrm{g}$ of protein were necessary to perform the whole procedure, since we took advantage of methodologies that require minimal amounts of protein: i) in vitro protein expression and purification, ii) antibody phage display and iii) scFv antibody microarray screening.

This approach avoids the production of considerable amounts of protein necessary for both, the immunization and the screening steps, which usually are the bottlenecks for antibody development. In our hands, a dedicated person could produce antibodies in about 4 weeks, calculating 5 working days per week: i) 3 days for amplification, DNA purification and in vitro protein expression and purification by TALON ${ }^{\mathrm{TM}}$ Dynabeads ${ }^{\circledR}$, ii) 8 days for three-four rounds of biopanning by phage display and E. coli amplification, iii) 3-4 days for printing and screening of scFv antibody microarrays and iv) 3-4 days for production and verification of the scFv results (Figure 5).

This methodology could be adapted to a highthroughput system. Indeed, all the techniques used in this report have been previously adapted to highthroughput assays $[8,9,22,34,47,48]$. One main advantage of our approach relies on the utilization of in vitro bacterial cell-free expression. Different reports support this expression strategy, because yields as low as $5 \mu \mathrm{g}$ of protein were enough to get antibodies. Proteins with recovery yields below this amount could be scaled up in vitro as much as necessary to obtain the $5 \mu \mathrm{g}$ of protein required for this approach.

Initially, cell-free expression was restricted by several limitations, especially for the expression of transmembrane proteins or proteins rich in disulfide bonds. However, advances in the in vitro technology have minimized these limitations by including several components, like 


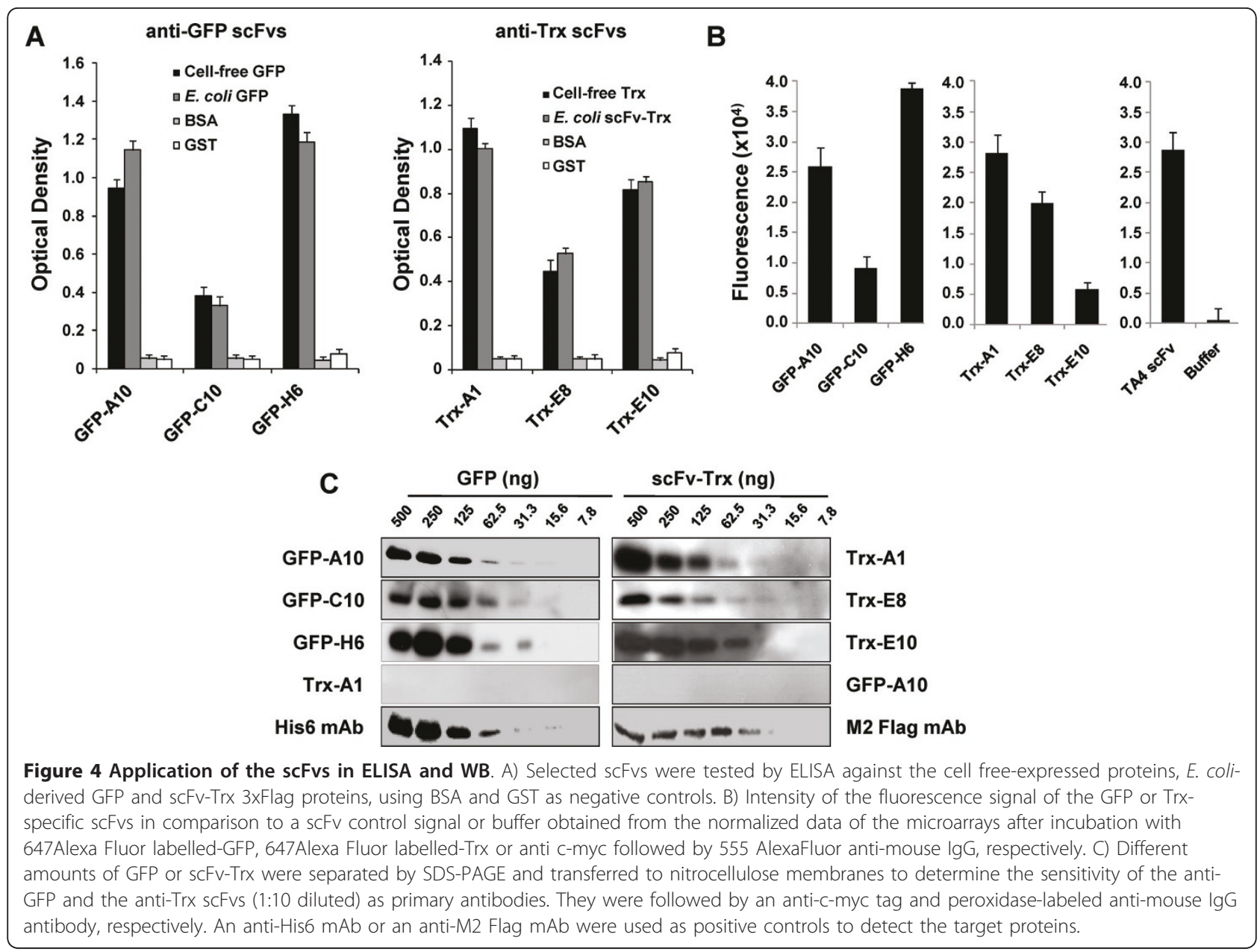

canine pancreatic microsomal membranes, different DTT ratios and protein disulfide isomerase for the correct folding and production of proteins presenting disulfide bonds or different detergents and lipid bilayers for the expression of membrane proteins [25,26,49-52].

The microarray format for antibody screening shows different advantages: i) consumes minimal amounts of proteins, ii) is very sensitive, iii) improves the specificity, and iv) is suitable for high-throughput screening of antibodies. At the same time that we identified a recombinant antibody to a particular protein, a global-binding profile is simultaneously generated because different antibodies produced against different proteins are printed in the same array, permitting the selection of only highly specific, non cross-reactive antibodies. With our microarray settings, we could print up to 4800 spots in a high-density antibody format per slide. Since, only 192 scFvs were tested in duplicate per antigen, we could significantly increase the multiplexing of this methodology by testing antibodies against 12 targets simultaneously in the same slide.
Moreover, the use of recombinant antibodies in microarray format did not alter significantly scFvs binding properties after printing. It has been described that only a fraction of antibodies work well after printing on the surface of microarrays, due to the loss of activity by denaturation or degradation during printing and array storage. To explore the fact that we could have been losing $60-80 \%$ of total scFvs due to denaturation in our antibody microarrays [5,53], we decided to test all the scFvs by ELISA to compare the performance of the microarray and verify the usefulness of antibody microarrays for identification of scFv binders. Interestingly, we were able to identify a similar number of $\mathrm{scFv}$ binders by both screenings with a coincidence of 62 and $75 \%$ for GFP and Trx, respectively. These data support the utilization of antibody microarrays for the screening step, while consuming only $0.5 \mu \mathrm{g}$ of 647 AlexaFluor protein.

Remarkably, scFvs were prepared by using a naïve scFv phage display library displaying multiple scaffolds (frameworks), avoiding the use of scFv antibody libraries 


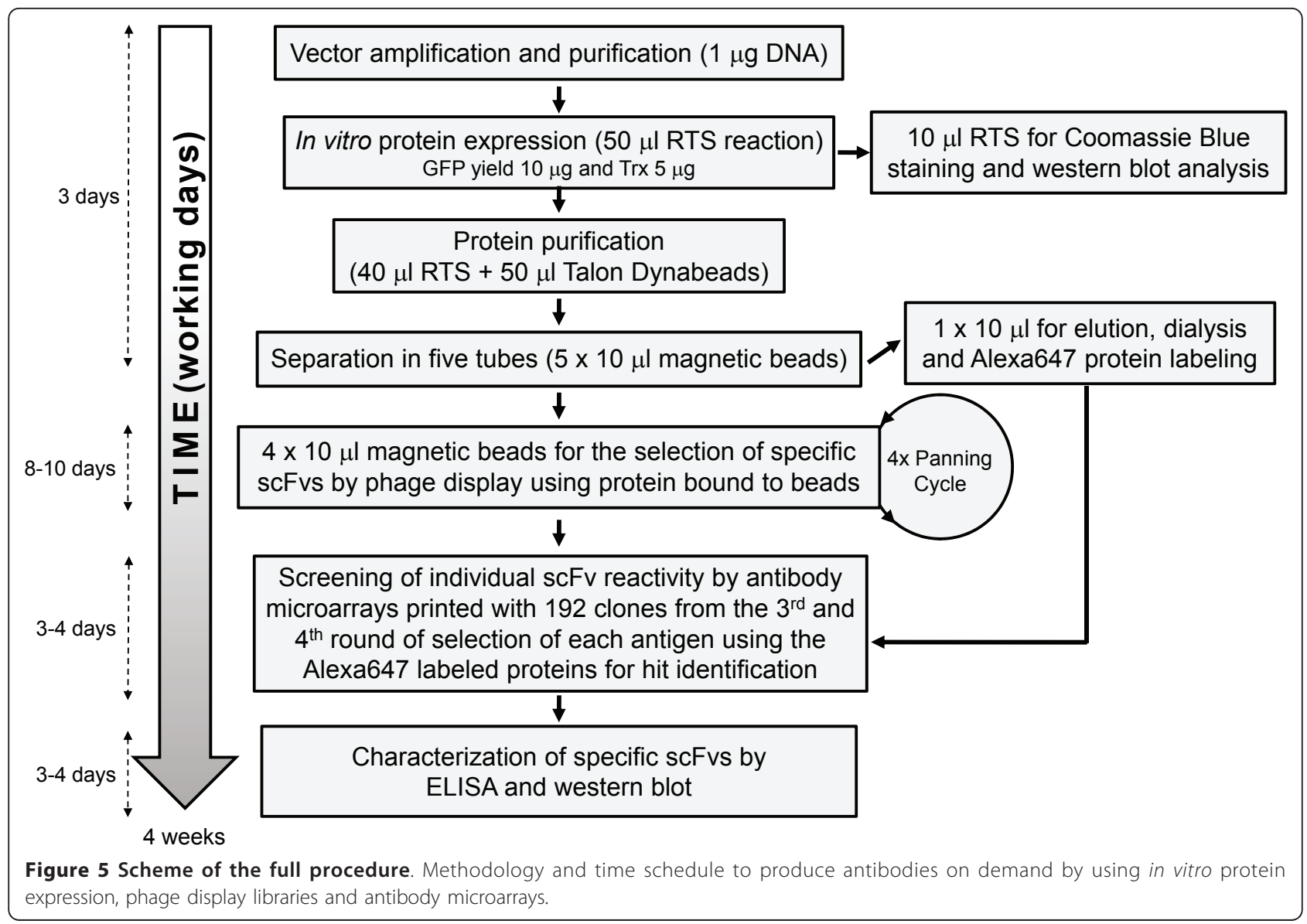

specifically designed for antibody microarrays, which usually possess one fixed scaffold [48].

\section{Conclusion}

We have developed a new and fast method to produce $\mathrm{scFv}$ antibodies by using only $5 \mu \mathrm{g}$ of cell-free expressed protein and a naive scFv antibody library in combination with an antibody microarray format for screening. The scFvs were useful for different applications (ELISA, antibody microarrays and western blot). This antibody production technology could be especially applicable to "difficult-to-express" or toxic proteins, or when the amount of available protein might be a limiting step.

\section{Methods}

In vitro protein expression, purification and

\section{characterization}

Plasmids pET32b-Trx or pIVEX-GFP were used in the cell free transcription/translation system to produce Trx or GFP, respectively. Plasmid DNA (1 $\mu \mathrm{g})$ was ethanol precipitated and used as template for in vitro transcription/ translation using the Rapid Translation System ${ }^{\circledR}$ (RTS) kit (Roche Applied System). RTS reactions containing DNA template in $50 \mu \mathrm{L}$ of solution $(12 \mu \mathrm{L}$ E.coli lysate, $10 \mu \mathrm{L}$ reaction mix, $12 \mu \mathrm{L}$ amino acids, $1 \mu \mathrm{L}$ methionine, $5 \mu \mathrm{L}$ reconstitution buffer and $1 \mu \mathrm{g}$ of DNA in $10 \mu \mathrm{L}$ RNAse-free water) were incubated at $30^{\circ} \mathrm{C}$ for $6 \mathrm{~h}$ at $300 \mathrm{rpm}$ in a Thermomixer (Eppendorf). $10 \mu \mathrm{l}$ RTS reaction for GFP and Trx was exclusively used to analyze the quality of the expressed and purified proteins with TALONTM Dynabeads ${ }^{\circledR}$ by Coomassie Blue staining of $10 \%$ SDS-PAGE gels or, alternatively, by immunoblotting using an anti-His6-tag antibody $(0.3 \mu \mathrm{g} / \mathrm{ml}$, Roche). One RTS reaction was used to determine the enrichment of the biopanning procedure and to verify the scFv binding by ELISA.

BSA (Sigma), E. coli-expressed GFP-His6 (GE) and an irrelevant scFv fused to Trx (3xFlag, His6-tagged) were used as control proteins in this study. GST-His6 and scFvTrx (3xFlag, His6) proteins were produced in E. coli according to established procedures [54]. Briefly, pET41b (Novagen) containing GST-cDNA and pSANG10-3F containing the cDNA encoding the scFv-Trx were used to transform BL21 (DE3) E. coli cells. His6-tagged proteins were then expressed and purified by affinity chromatography on a HiTrap chelating column (GE Healthcare). 


\section{Selection of protein-specific scFvs from phagemid libraries}

Human scFv Mehta libraries (a kind gift of Wayne Marasco, Dana-Farber Cancer Center. USA) were used for scFv production $[55,56]$. Mehta scFvs contain a c-myc tag for detection and purification. Phage display selections were performed using the proteins attached to TALON Dynabeads. Briefly, cell-free expressed proteins were attached to TALONTM Dynabeads through the His6 tag by incubating $40 \mu \mathrm{L}$ of the RTS reaction with $50 \mu \mathrm{L}$ of magnetic beads. Five equal aliquots were prepared, four for the rounds of selection and one for direct labelling of the proteins.

After exhaustive washing with PBS, magnetic beads were blocked with 3\% BSA in PBS (PBS-BSA) for $1 \mathrm{~h}$ at room temperature. After washing, $100 \mu \mathrm{l}$ of Mehta I and II libraries, diluted 1:10 in PBS-BSA, pre-incubated with magnetic beads to remove non-specific binders, were added to the solution and incubated for $2 \mathrm{~h}$ at room temperature. We performed four rounds of biopanning to get specific scFvs against GFP and Trx. Each round of selection included a negative subtraction of the phages against empty TALON ${ }^{\mathrm{TM}}$ Dynabeads ${ }^{\circledR}$. Beads were washed 5 times with PBS-0.1\% Tween during 2 min at room temperature and $40 \mathrm{rpm}$ in a lab roller. Prior to elution a final washing step with PBS was performed to remove detergent from the media. Then, phages were eluted with $100 \mu \mathrm{L}$ of $0.1 \mathrm{M}$ glycine, $\mathrm{pH} 2.7$ during $10 \mathrm{~min}$ at room temperature in a lab roller at 40 rpm. Finally, phages were neutralized with $20 \mu \mathrm{L}$ of $1 \mathrm{M}$ Tris, $\mathrm{pH} 9$.

The amplification of the phages during the four rounds of biopanning was performed essentially as described by Barbas et al. [11] with minor modifications. Briefly, $100 \mu \mathrm{L}$ of eluted phages from the first round of selection or $50 \mu \mathrm{L}$ from the second and successive rounds of selection were used to infect $2 \mathrm{~mL}$ exponential phase XL1 Blue E. coli cells during $15 \mathrm{~min}$ at room temperature. Then, $6 \mathrm{~mL}$ of SB medium (10 g MOPS, $30 \mathrm{~g}$ of tryptone, $20 \mathrm{~g}$ of yeast extract in $1 \mathrm{~L}$ of water at $\mathrm{pH} 7.0)$ containing $1.6 \mu \mathrm{L}$ of $100 \mathrm{mg} / \mathrm{mL}$ carbenicillin (Sigma) and $12 \mu \mathrm{L}$ of $5 \mathrm{mg} / \mathrm{mL}$ tetracycline were added to the cell culture and further incubated at $37^{\circ} \mathrm{C}$ for $1 \mathrm{~h}$ at $250 \mathrm{rpm}$. Then, $2.4 \mu \mathrm{L}$ of $100 \mathrm{mg} / \mathrm{mL}$ carbenicillin (Sigma) were added to the cell culture for an additional $1 \mathrm{~h}$ at $250 \mathrm{rpm}$ at $37^{\circ} \mathrm{C}$. Then, $1 \mathrm{~mL}$ VCSM13 helper phage $\left(10^{12}\right.$ to $\left.10^{13} \mathrm{pfu}\right)$ was added to the $8-\mathrm{mL}$ cell culture together with $91 \mathrm{~mL}$ of prewarmed SB medium containing $46 \mu \mathrm{L}$ of $100 \mathrm{mg} / \mathrm{mL}$ carbenicillin and $184 \mu \mathrm{L}$ of $5 \mathrm{mg} / \mathrm{ml}$ tetracycline. The media was further incubated at $300 \mathrm{rpm}$ for $2 \mathrm{~h}$ at $37^{\circ} \mathrm{C}$. Finally, $140 \mu \mathrm{L}$ of $50 \mathrm{mg} / \mathrm{mL}$ kanamycin was added to the medium and the solution was further incubated overnight at $37^{\circ} \mathrm{C}$.
The day after, the culture was centrifuged at $4000 \mathrm{rpm}$ for $15 \mathrm{~min}$ at $4^{\circ} \mathrm{C}$. Supernatant containing phage suspension was mixed with $4 \mathrm{~g}$ of PEG-8000 (Sigma) and 3 $\mathrm{g}$ of $\mathrm{NaCl}$ (Merck) until complete dissolution and, then, was kept on ice for $30 \mathrm{~min}$. Then, phages were centrifuged at $15000 \mathrm{~g}$ for $15 \mathrm{~min}$ and $4^{\circ} \mathrm{C}$. Phages were resuspended in $2 \mathrm{~mL}$ of $1 \%$ BSA (Sigma) in PBS. Then, $100 \mu \mathrm{L}$ out of $2 \mathrm{~mL}$ phage solution were directly used in subsequent rounds of biopanning as described above.

\section{Production of human scFv microarrays}

Ninety six colonies were randomly picked from the $3^{\text {rd }}$ and $4^{\text {th }}$ round of biopanning against GFP and Trx. Individual colonies were added to 96 -well plates containing $200 \mu \mathrm{L}$ of $2 \mathrm{xTY}, 100 \mu \mathrm{g} / \mathrm{ml}$ ampicillin and $1 \%$ glucose and grown overnight at $37^{\circ} \mathrm{C}$. Next day, cultures were diluted 1:100 in 96-well plates containing $200 \mu \mathrm{L}$ of $2 x T Y, 100 \mu \mathrm{g} / \mathrm{ml}$ ampicillin and $0.1 \%$ glucose. IPTG was added at $1 \mathrm{mM}$ final concentration and cultures were incubated overnight at $30^{\circ} \mathrm{C}$. For scFv purification, cells were spun down, resuspended in $100 \mu \mathrm{l}$ TES $(10 \mathrm{mM}$ Tris- $\mathrm{HCl} \mathrm{pH}$ 8.0, $0.1 \mathrm{mM}$ EDTA, $150 \mathrm{mM} \mathrm{NaCl}, 20 \%$ sucrose) and kept on ice for $30 \mathrm{~min}$. The periplasmic fraction was obtained by centrifugation at $1800 \mathrm{rpm}$ for $10 \mathrm{~min}[41,57]$. Then, scFv-containing periplasms were diluted 1:2 in PBS, 0.1\% Tween 20 (PBST) and directly arrayed in duplicate onto FAST slides (Whatman). AntiT7 mouse monoclonal antibody $(0.1 \mathrm{mg} / \mathrm{mL}$, Novagen $)$ and $1: 10$ fold dilutions starting at $0.1 \mathrm{mg} / \mathrm{mL}$ of TA4 scFv, which contains a c-myc tag at the C-terminus [40], were used as positive controls and PBST as negative control.

FAST nitrocellulose slides (Schleicher \& Schuell, Whatman) were printed at $20^{\circ} \mathrm{C}$ and $45 \%$ of humidity using a microarrayer (Omnigrid, GeneMachines) with 4 micro-spotting $70 \mu \mathrm{m}$ diameter stealth pins with reservoir (TeleChem). Pins were fixed to dip once and prespot 10 times before printing approximately $3 \mathrm{~nL}$ of solution per spot. The separation between dots was 350 $\mu \mathrm{m}$. Slides were kept overnight inside the arrayer at $20^{\circ}$ $\mathrm{C}$ and $75 \%$ of humidity for immobilizing the antibodies. Nitrocellulose slides were stored at $-20^{\circ} \mathrm{C}$ until use.

\section{scFv microarray processing and data acquisition}

Cell-free expressed GFP and Trx were labelled with a 647Alexa Fluor "Microscale Protein Labelling" kit (Invitrogen). Proteins attached to TALONTM Dynabeads ${ }^{\circledR}$ were eluted with $50 \mathrm{mM}$ phosphate buffer, $0.3 \mathrm{M} \mathrm{NaCl}$, $150 \mathrm{mM}$ imidazole $\mathrm{pH}$ 8.0, and extensively dialysed against PBS. Purified proteins were lyophilised to concentrate before labelling.

Microarray slides were blocked with $4 \%$ skimmed milk in PBS (MPBS) for $1 \mathrm{~h}$ at room temperature. Then, either cell free AlexaFluor 647-labelled GFP or Trx (1 
$\mu \mathrm{g} / \mathrm{mL})$, E. coli-expressed GFP or $\operatorname{Trx}(1 \mu \mathrm{g} / \mathrm{mL})$ or antic-myc antibody $(1 \mu \mathrm{g} / \mathrm{mL}$, Roche $)$ in $4 \%$ MPBS were added for $1 \mathrm{~h}$ at room temperature and incubated in SecureSeal hybridization chambers (Grace Bio-Labs). The microarrays were washed three times with PBST during $10 \mathrm{~min}$. For detecting AlexaFluor 647-GFP or Trx, microarrays were air dried and directly scanned as described below. For detecting bound GFP and Trx proteins (or controls GFP-His6 and scFv-Trx-3xFlag), slides were incubated with rabbit polyclonal anti-GFP $(0.2 \mu \mathrm{g} /$ $\mathrm{mL}$, Abcam) or monoclonal anti-Flag $(10 \mu \mathrm{g} / \mathrm{mL}$, Sigma) for $1 \mathrm{~h}$, washed and incubated with Alexa Fluor 555labeled goat anti-rabbit IgG $(1 \mu \mathrm{g} / \mathrm{mL}$, Invitrogen $)$ or Alexa Fluor 555-labeled goat anti-mouse IgG $(1 \mu \mathrm{g} / \mathrm{mL}$, Invitrogen), respectively, for $1 \mathrm{~h}$ in the dark. For detecting c-myc antibody, slides were incubated with Alexa Fluor 555-labeled goat anti-mouse IgG antibodies $(1 \mu \mathrm{g} /$ $\mathrm{mL}$ ). After three $10 \mathrm{~min}$ washes with PBST, microarrays were air dried and scanned with the ScanArray ${ }^{\mathrm{TM}} 5000$ (Packard BioChip Technologies) using $635 \mathrm{~nm}$ and 532 $\mathrm{nm}$ lasers for Alexa 647 and Alexa 555, respectively. The Genepix Pro 4.0 image analysis software was used for quantification and analysis of the results.

\section{Sequence analysis}

Phagemide DNAs from individual scFv positive colonies were amplified by PCR with the primers: pELB_forward, 5'-CATAATGAAATACCTATTGCCTA-3' and cmyc_reverse, 5'-CTTATTAGCGTTTGCCATT-3 [55]. Briefly, the cDNA encoding the scFvs was amplified using an initial denaturation step at $94^{\circ} \mathrm{C}$ for $2 \mathrm{~min}$, followed by 30 cycles of $1 \mathrm{~min}$ at $94^{\circ} \mathrm{C}, 1 \mathrm{~min}$ at $55^{\circ} \mathrm{C}$ and $1 \mathrm{~min}$ at $72^{\circ} \mathrm{C}$ and a final step of $7 \mathrm{~min}$ at $72^{\circ} \mathrm{C}$. Exonuclease I (USB) and shrimp alkaline phosphatase (USB) were added to the PCR products to remove any contaminant. Sequencing was carried out in an ABI7002 DNA sequencer (Applied Biosystems).

\section{ELISA and Western Blot analysis}

For ELISA, flexible microtiter plates (Falcon, BD Biosciences) were coated overnight with $0.3 \mu \mathrm{g} /$ well of the cell-free purified GFP or Trx. BSA or GST were used as negative controls. After washing three times with PBS, plates were blocked with $2 \%$ MPBS for $2 \mathrm{~h}$ at room temperature. Then, either different dilutions of the phage suspension or the periplasmic fractions were tested in the presence of $2 \%$ MPBS for $2 \mathrm{~h}$ at $37^{\circ} \mathrm{C}$. After washing, peroxidase-labelled anti-M13 (1:5000 dilution in $2 \%$ MPBS) or anti-c-myc $(1 \mu \mathrm{g} / \mathrm{mL}$, Roche $)$ to detect the phages or scFvs, respectively, were added for $1 \mathrm{~h}$ at $37^{\circ} \mathrm{C}$. After washing, peroxidase reaction was developed with 3,3',5,5'-tetramethylbenzidine (TMB) substrate (Sigma). The reaction was stopped with $1 \mathrm{M}$ $\mathrm{H}_{2} \mathrm{SO}_{4}$ and the absorption measured at $450 \mathrm{~nm}$.
For western blot analysis, proteins were transferred to nitrocellulose membranes. GFP and Trx were detected by using peroxidase-conjugated anti-His $6(0.3 \mu \mathrm{g} / \mathrm{ml}$, Roche). Alternatively, GFP-His6 or scFv-Trx control proteins were detected with the corresponding scFvs at $100 \mathrm{ng} / \mathrm{mL}$ concentration. The signal was developed using an anti-c-myc tag ( $1 \mu \mathrm{g} / \mathrm{mL}$, Roche) followed by peroxidase-conjugated anti-mouse IgG $(0.2 \mu \mathrm{g} / \mathrm{mL}$, Sigma). All the incubations were for $1 \mathrm{~h}$ at $37^{\circ} \mathrm{C}$. ECL reagent was used for final detection.

Moreover, we have generated the fact sheets reporting the Minimum Information

About a Protein Affinity Reagent (MIAPAR), where we have included all the procedures and data reported for the scFvs produced in this study against GFP (Additional File 1) and $\operatorname{Trx}$ (Additional File 2).

\section{Additional material}

Additional file 1: MIAPAR-compliant document for human anti-GFP scFvs. The file includes the MIAPAR-compliant document presenting all the information about the production of human anti-GFP scFvs described in the manuscript.

Additional file 2: MIAPAR-compliant document for human anti-Trx scFvs. The file includes the MIAPAR-compliant document presenting all the information about the production of human anti-Trx scFvs described in the manuscript.

\section{List of Abbreviations}

scFvs: single-chain variable fragments; GFP: Green Fluorescent Protein; mAbs: monoclonal antibodies; MMP7: matrix metalloproteinase-7; pAbs: polyclonal antibodies; Trx: Thioredoxin.

\section{Acknowledgements and funding}

RB was supported by a JAE-Doc contract (CSIC). AP is a recipient of a predoctoral FPI grant of the Spanish Ministry of Science and Innovation. This research was supported by grants from the Spanish Ministry of Science and Innovation BIO2009-08818 and Colomics Programme of the regional government of Madrid.

\section{Authors' contributions}

$\mathrm{IB}, \mathrm{RB}$ and AP carried out the experimental work. IB and RB drafted the manuscript. IC conceived the study, supervised the experiments and wrote the manuscript. All authors read and approved the final manuscript.

Received: 10 December 2010 Accepted: 2 June 2011

Published: 2 June 2011

\section{References}

1. Agaton C, Uhlen M, Hober S: Genome-based proteomics. Electrophoresis 2004, 25:1280-1288.

2. Hanash S: Disease proteomics. Nature 2003, 422:226-232

3. Persson A, Hober S, Uhlen M: A human protein atlas based on antibody proteomics. Curr Opin Mol Ther 2006, 8:185-190.

4. Uhlen M, Bjorling E, Agaton C, Szigyarto CA, Amini B, Andersen E, Andersson AC, Angelidou P, Asplund A, Asplund C, et al: A human protein atlas for normal and cancer tissues based on antibody proteomics. $\mathrm{Mol}$ Cell Proteomics 2005, 4:1920-1932.

5. Haab BB: Applications of antibody array platforms. Curr Opin Biotechnol 2006, 17:415-421

6. Jonasson $\mathrm{K}$, Berglund $\mathrm{L}$, Uhlen M: The 6th HUPO Antibody Initiative (HAI) workshop: sharing data about affinity reagents and other recent 
developments. September 2009, Toronto, Canada. Proteomics 2010, 10:2066-2068.

7. Dubel S, Stoevesandt O, Taussig MJ, Hust M: Generating recombinant antibodies to the complete human proteome. Trends Biotechnol 2010, 28:333-339.

8. Mersmann M, Meier D, Mersmann J, Helmsing S, Nilsson P, Graslund S, Colwill K, Hust M, Dubel S: Towards proteome scale antibody selections using phage display. Nat Biotechnol 2010, 27:118-128.

9. Hust M, Meyer T, Voedisch B, Rulker T, Thie H, El-Ghezal A, Kirsch Ml, Schutte M, Helmsing S, Meier D, et al: A human scFv antibody generation pipeline for proteome research. J Biotechnol 2010, 152:159-170.

10. Chambers RS: High-throughput antibody production. Curr Opin Chem Biol 2005, 9:46-50.

11. Barbas CF, Burton DR, Scott JK, Silverman GJ: Phage Display: A Laboratory Manual. Cold Spring Harbor Laboratory Press, Cold Spring Harbor, NY; 2001.

12. Laffly $E$, Sodoyer R: Monoclonal and recombinant antibodies, 30 years after. Hum Antibodies 2005, 14:33-55.

13. Winter G, Griffiths AD, Hawkins RE, Hoogenboom HR: Making antibodies by phage display technology. Annu Rev Immunol 1994, 12:433-455.

14. Liu B, Huang L, Sihlbom C, Burlingame A, Marks JD: Towards proteomewide production of monoclonal antibody by phage display. $J \mathrm{Mol}$ Biol 2002, 315:1063-1073

15. Hoet RM, Cohen EH, Kent RB, Rookey K, Schoonbroodt S, Hogan S, Rem L, Frans N, Daukandt M, Pieters $\mathrm{H}$, et al: Generation of high-affinity human antibodies by combining donor-derived and synthetic complementaritydetermining-region diversity. Nat Biotechnol 2005, 23:344-348.

16. Adams GP, Schier R, McCall AM, Simmons HH, Horak EM, Alpaugh RK, Marks JD, Weiner LM: High affinity restricts the localization and tumor penetration of single-chain fv antibody molecules. Cancer Res 2001, 61:4750-4755

17. Jain RK: Delivery of molecular medicine to solid tumors. Science 1996, 271:1079-1080.

18. Hwang WY, Foote J: Immunogenicity of engineered antibodies. Methods 2005, 36:3-10

19. Schroff RW, Foon KA, Beatty SM, Oldham RK, Morgan AC Jr: Human antimurine immunoglobulin responses in patients receiving monoclonal antibody therapy. Cancer Res 1985, 45:879-885.

20. Kalyn R: Overview of targeted therapies in Oncology. J Oncol Pharm Pract 2007, 13:199-205.

21. Glennie MJ, Johnson PW: Clinical trials of antibody therapy. Immunol Today 2000, 21:403-410.

22. Pershad K, Pavlovic JD, Graslund S, Nilsson P, Colwill K, Karatt-Vellatt A, Schofield DJ, Dyson MR, Pawson T, Kay BK, et al: Generating a panel of highly specific antibodies to 20 human SH2 domains by phage display. Protein Eng Des Sel 2010, 23:279-288.

23. Aoki M, Matsuda T, Tomo Y, Miyata Y, Inoue M, Kigawa T, Yokoyama S: Automated system for high-throughput protein production using the dialysis cell-free method. Protein Expr Purif 2009, 68:128-136.

24. Goshima N, Kawamura Y, Fukumoto A, Miura A, Honma R, Satoh R, Wakamatsu A, Yamamoto J, Kimura K, Nishikawa T, et al: Human protein factory for converting the transcriptome into an in vitro-expressed proteome. Nat Methods 2008, 5:1011-1017.

25. He M: In vitro protein expression: an emerging alternative to cell-based approaches. Nat Biotechnol 2010, 28:209-210.

26. Junge F, Haberstock S, Roos C, Stefer S, Proverbio D, Dotsch V, Bernhard F: Advances in cell-free protein synthesis for the functional and structural analysis of membrane proteins. Nat Biotechnol 2010, 28:262-271.

27. Jackson AM, Boutell J, Cooley N, He M: Cell-free protein synthesis for proteomics. Brief Funct Genomic Proteomic 2004, 2:308-319.

28. Endo Y, Sawasaki T: High-throughput, genome-scale protein production method based on the wheat germ cell-free expression system. Biotechnol Adv 2003, 21:695-713.

29. Cappuccio JA, Hinz AK, Kuhn EA, Fletcher JE, Arroyo ES, Henderson PT, Blanchette CD, Walsworth VL, Corzett MH, Law RJ, et al: Cell-free expression for nanolipoprotein particles: building a high-throughput membrane protein solubility platform. Methods Mol Biol 2009, 498:273-296.

30. Katzen F, Chang G, Kudlicki W: The past, present and future of cell-free protein synthesis. Trends Biotechnol 2005, 23:150-156.

31. He M: Cell-free protein synthesis: applications in proteomics and biotechnology. Nat Biotechnol 2008, 25:126-132.
32. Hoffmann M, Nemetz C, Madin K, Buchberger B: Rapid translation system: a novel cell-free way from gene to protein. Biotechnol Annu Rev 2004, 10:1-30.

33. Lopez JE, Beare PA, Heinzen RA, Norimine J, Lahmers KK, Palmer GH, Brown WC: High-throughput identification of T-lymphocyte antigens from Anaplasma marginale expressed using in vitro transcription and translation. J Immunol Methods 2008, 332:129-141.

34. Yokoyama S, Hirota H, Kigawa T, Yabuki T, Shirouzu M, Terada T, Ito Y, Matsuo $Y$, Kuroda $Y$, Nishimura $Y$, et al: Structural genomics projects in Japan. Nat Struct Biol 2000, 7(Suppl):943-945.

35. Seki E, Matsuda N, Yokoyama S, Kigawa T: Cell-free protein synthesis system from Escherichia coli cells cultured at decreased temperatures improves productivity by decreasing DNA template degradation. Anal Biochem 2008, 377:156-161.

36. Kigawa T, Yabuki T, Yoshida Y, Tsutsui M, Ito Y, Shibata T, Yokoyama S: Cellfree production and stable-isotope labeling of milligram quantities of proteins. FEBS Lett 1999, 442:15-19.

37. Chandra H, Srivastava S: Cell-free synthesis-based protein microarrays and their applications. Proteomics 2010, 10:717-730.

38. Apponyi MA, Ozawa K, Dixon NE, Otting G: Cell-free protein synthesis for analysis by NMR spectroscopy. Methods Mol Biol 2008, 426:257-268.

39. Dixon NE: Cell-free protein synthesis. FEBS J 2006, 273:4131-4132

40. Barderas R, Shochat S, Martinez-Torrecuadrada J, Altschuh D, Meloen R, Casal $\mathrm{Jl}$ A fast mutagenesis procedure to recover soluble and functional scFvs containing amber stop codons from synthetic and semisynthetic antibody libraries. J Immunol Methods 2006, 312:182-189.

41. Barderas R, Desmet J, Timmerman P, Meloen R, Casal Jl: Affinity maturation of antibodies assisted by in silico modeling. Proc Natl Acad Sci USA 2008, 105:9029-9034.

42. Babel I, Barderas R, Diaz-Uriarte R, Moreno V, Suarez A, FernandezAcenero MJ, Salazar R, Capella G, Casal Jl: Identification of MST1/STK4 and SulF1 Proteins as Autoantibody Targets for the Diagnosis of Colorectal Cancer by Using Phage Microarrays. Mol Cell Proteomics 2011, 10:M110 001784.

43. Tyers M, Mann M: From genomics to proteomics. Nature 2003, 422:193-197.

44. Uhlen M, Ponten F: Antibody-based proteomics for human tissue profiling. Mol Cell Proteomics 2005, 4:384-393.

45. Haab BB: Antibody arrays in cancer research. Mol Cell Proteomics 2005, 4:377-383.

46. De Masi F, Chiarella P, Wilhelm H, Massimi M, Bullard B, Ansorge W, Sawyer A: High throughput production of mouse monoclonal antibodies using antigen microarrays. Proteomics 2005, 5:4070-4081.

47. Walter $\mathrm{G}$, Konthur Z, Lehrach $\mathrm{H}$ : High-throughput screening of surface displayed gene products. Comb Chem High Throughput Screen 2001, 4:193-205.

48. Borrebaeck CA, Wingren C: High-throughput proteomics using antibody microarrays: an update. Expert Rev Mol Diagn 2007, 7:673-686.

49. Kaiser L, Graveland-Bikker J, Steuerwald D, Vanberghem M, Herlihy K, Zhang S: Efficient cell-free production of olfactory receptors: detergent optimization, structure, and ligand binding analyses. Proc Natl Acad Sci USA 2008, 105:15726-15731.

50. Schwarz D, Daley D, Beckhaus T, Dotsch V, Bernhard F: Cell-free expression profiling of E. coli inner membrane proteins. Proteomics 2010, 10:1762-1779

51. Goerke AR, Swartz JR: Development of cell-free protein synthesis platforms for disulfide bonded proteins. Biotechnol Bioeng 2008, 99:351-367.

52. Gura T: Therapeutic antibodies: magic bullets hit the target. Nature 2002, 417:584-586.

53. Haab BB, Dunham MJ, Brown PO: Protein microarrays for highly parallel detection and quantitation of specific proteins and antibodies in complex solutions. Genome Biol 2001, 2:RESEARCH0004.

54. Madoz-Gurpide J, Lopez-Serra P. Martinez-Torrecuadrada JL, Sanchez L, Lombardia L, Casal Jl: Proteomics-based validation of genomic data: applications in colorectal cancer diagnosis. Mol Cell Proteomics 2006 5:1471-1483.

55. Sui J, Li W, Murakami A, Tamin A, Matthews LJ, Wong SK, Moore MJ, Tallarico AS, Olurinde $M$, Choe $H$, et al: Potent neutralization of severe acute respiratory syndrome (SARS) coronavirus by a human mAb to S1 
protein that blocks receptor association. Proc Natl Acad Sci USA 2004, 101:2536-2541.

56. Barderas R, Shochat $S$, Timmerman P, Hollestelle MJ, Martinez-

Torrecuadrada JL, Hoppener JW, Altschuh D, Meloen R, Casal Jl: Designing antibodies for the inhibition of gastrin activity in tumoral cell lines. Int J Cancer 2008, 122:2351-2359.

57. Martinez-Torrecuadrada JL, Cheung LH, Lopez-Serra P, Barderas R,

Canamero M, Ferreiro S, Rosenblum MG, Casal J: Antitumor activity of fibroblast growth factor receptor 3-specific immunotoxins in a xenograft mouse model of bladder carcinoma is mediated by apoptosis. Mol Cancer Ther 2008, 7:862-873.

doi:10.1186/1472-6750-11-61

Cite this article as: Babel et al: Antibodies on demand: a fast method for the production of human scFvs with minimal amounts of antigen. BMC Biotechnology 2011 11:61.

\section{Submit your next manuscript to BioMed Central} and take full advantage of:

- Convenient online submission

- Thorough peer review

- No space constraints or color figure charges

- Immediate publication on acceptance

- Inclusion in PubMed, CAS, Scopus and Google Scholar

- Research which is freely available for redistribution

Submit your manuscript at www.biomedcentral.com/submit
C Biomed Central 